\title{
IDENTIFYING AND RANKING FINANCIAL PARAMETERS OF BANKS USING FUZZY AHP METHOD
}

\author{
UDC: $336.71: 510.64$ \\ Original Scientific Paper \\ Ali Reza AFSHARI ${ }^{*}$, Hadi SAEIDI ${ }^{2}$, Parisa HATAMI ${ }^{2}$ \\ ${ }^{1}$ Department of Industrial Engineering, Shirvan Branch, Islamic Azad University, Shirvan, Iran \\ E-mail: afshari@mshdiau.ac.ir \\ ${ }^{2}$ Department of Accounting, Shirvan Branch, Islamic Azad University, Shirvan, Iran
}

Paper received: 24.03.2021; Paper accepted: 06.04.2021

\begin{abstract}
This study has been done with the aim to identify and rank the financial parameters of public and private banks in the North Khorasan Province. The method of this study was quantitative and cross-sectional survey and based on comparative and field study. In this research, after studying library research and studies and oral interviews, a researcher-made questionnaire was set of the financial parameters of banks. In addition, among 120 employees and 60 managers of governmentowned branches and privately distributed in the North Khorasan Province. To analyze the information obtained AHP technique for ranking the factors by using Expert Choice software. Results showed that an instantaneous factor with a relative weight of 0,106 is in the first rank followed by the operating cash flow attributable to operational activities with a relative weight of 0,103 ranked as the second and a long-term debt ratio with a relative weight of 0,084 ranked as the third that have importance for the financial parameters of banks.
\end{abstract}

Keywords: Bank performance; Performance evaluation; Fuzzy analytic hierarchy process (FAHP); Multi-criteria decision making (MCDM); Fuzzy Decision Making.

\section{INTRODUCTION}

Economic institutions and enterprises, in particular banks, need large capital to survive, continue and develop their activities (Berger \& Bouwman, 2013). They also depend heavily on financial markets for supply of their required capital. The role played by these markets is to provide the necessary funds for institutions and banks. One of the main points of interest for financial managers of financial institutions is the ways and the amount of funding (Pilbeam, 2018). Cash is one of the most important and a vital source of an economic unit and its management is required to forecast future cash flows. Investors, creditors and other accounting information users need to have cash flow information to make financial and investment decisions. Operating cash flow constitutes the main part of a business unit cash flow (Gordon et al., 2017). Since managers are responsible for improvement of liquidity, it is important for them to consider the effects of financing ways. In addition, how they use the revenues obtained on the cash flow. Also, the method of financing may be related to earnings per share, financial risk, and shareholders' percentage of ownership (Bouma et al., 2017). The importance of cash flows for users led the US Financial Accounting Standards Board to issue Cash Flow Statement in 1987 (Bowen et al., 1987). The cash flow statement can provide important information about amounts, reasons, and intervals between profit and cash receipts and payments. According to the US Financial Accounting Standards Board (Puro, 1984), cash flow statement should present cash inflows and outflows of financial units in five sections including investing activities, operating activities, income taxes, return on investment and dividend paid for financing and financing activities (Barth et al., 2001).

Banks are the actors of financial market and the whole system of financing the economy; it means that they are becoming, directly or indirectly, the drivers and mechanisms for control of financial system without which reproduction process is 


$\begin{array}{ll}\text { A. } R \text {. Afshari } & \text { Identifying and ranking the financial parameters of banks } \\ \text { et al. } & \text { using fuzzy AHP method }\end{array}$

practically impossible (De Haan et al., 2009). Banks, as specific financial institutions, play a pivotal role in the financial system, due to the tasks they perform, as well as the relative size of financial capacity in the accounts. The activity of banks and, generally, banking industry, is undoubtedly one of the most important sectors of the economy in each country. A bank is defined as an enterprise or institution whose ongoing and continuous activities include, on one hand, the provision of financial services, and on the other hand, deposits from the public (Kashyap et al., 2002). The simultaneous combination of these two activities is the most distinctive characteristic of banks because the largest portion of the money and credit granted by a bank comes from public funds and deposits. One of the factors that may play a significant role in achieving the goal of sustained economic growth is the financial sector development in a country. The financial sector consists of various markets including money market and capital market. The financial sector development is important because an efficient financial sector plays a vital role in funding for investment and optimization of the resource allocation mechanism (Fund \& Bank, 2017). Iran has a closed financial system that means that foreign financial services providers are not allowed to enter Iranian markets and to provide Iranians with financial services under equal conditions with domestic financial services providers. Financial deepening in the monetary and banking glossary is a situation in which the share of monetary assets increases more rapidly than the share of nonmonetary assets. For example, a country may have a high liquidity/gross domestic product ratio; however, it may not be much developed in terms of financial system development (Kothari \& Barone, 2006).

According to studies performed, banks activities in a competitive environment with less government intervention, money market concentration and possibility for entry of more foreign banks will increase efficiency and growth (Beck, 2008). In addition, financial liberalization through financial development and financial deepening makes the domestic financial markets ready to compete with foreign financial markets. Financial liberalization involves all components of the financial system including financial markets, financial institutions and monetary, fiscal and currency policies (Wyplosz, 2002). Iran's financial system is not an exception and faces many fluctuations in banking and non-banking sectors and monetary policies, especially in the banking sector of the country where there is a constrained financial system with excessive control (Nikpour et al., 2018). The increasing establishment and expansion of business enterprises requires significant financial resources that founders cannot afford. The capital market provides banks with an opportunity to secure their required financial resources through the supply of securities (Yoshino \& Taghizadeh-Hesary, 2017). In other words, the capital market serves as a way to transfer resources from savers to consumers of financial resources and plays a vital role in a country's economy by providing the required capital of enterprises and the optimal allocation of resources. Using the resources obtained, managers make effort to survive and grow their organization (Sirmon et al., 2011). This is despite the fact that severe competitive conditions, financial, economic and political crises, and legal and property requirements have led banks to demand more resources, as well as re-invest the resources derived from the operations outcomes of the economic unit, which are owned by owners, within the economic unit (Cilizoglu, 2018).

The concept of performance is defined in terms of efficiency and effectiveness, as effectiveness refers to the extent at which a goal is achieved, and efficiency refers to the issue of how resources are economically used to achieve a goal, so they can be considered two important dimensions of performance (Abubakar et al., 2019). That is, there may be both internal factors (efficiency) and external factors (effectiveness) for given parts of performance, and therefore, performance is a function of efficiency and effectiveness of the activities performed. Common frameworks for various financing methods are borrowing, cash flows and use of common stock (Cohen et al., 2006). As long as they struggle to survive and require themselves to be present in the national and international fields, banks need to underpin the principle of continuous improvement. This may not be achieved unless the performance management is improved. This is improved by getting the required feedback from the internal and external environments, analyzing the strengths, weaknesses, opportunities and threats, accountability, and customer satisfaction by establishing and implementing an appropriate performance appraisal system. Different methods of financing make a significant contribution to flexibility of plans, objectives and missions of organizations in today's dynamic environment (Morozko et al., 2018). Evaluation and 
measurement of performance and its development require building and boosting the organizational culture. Unfortunately, in Iran, due to underdeveloped financial markets on one hand, and the lack of proper institutional and legal foundations in this area, banks have not yet been able to utilize financing methods. Therefore, if the investment expenditures with positive net present value are higher than domestic cash flows, a bank may discard investments in order to avoid issuing risky securities for financing (Bowen et al., 1986).

In the financial services sector, especially in activities related to global banking, there is a growing need for performance evaluation (Hermes $\&$ Hudon, 2018). Because of increasing uncertainty and competition in global banking markets, performance evaluation using fuzzy techniques provides clear and reliable information (Amile et al., 2013). The main purpose of this research is to provide support for decision making enabling decision makers to measure the effectiveness of banks through the application of multi-criteria decision-making. In this regard, the present study suggests a model for assessment of performance of banking system using fuzzy analytic hierarchy process (Saaty, 1980). FAHP method is used to determine the priority weights of criteria, which is then used as the input weights of criteria to rank banks. The purpose of the present study is to identify and rank the financial parameters of public banks of the North Khorasan Province through the application of hierarchical analysis methods. In short, the purpose of this research is to identify and rank financial parameters of banks through the application of AHP method. Secondary objectives are:

- Identification of factors affecting financial parameters of banks

- Ranking factors affecting financial parameters of banks

The results of this study are very important to be used in identification of financial parameters of banks.

\section{MATERIALS AND METHODS}

This research is a basic/fundamental pure research in terms of purpose and is a descriptive-survey method in terms of data collection method.

\section{Research design}

The statistical population refers to the total number of people who, in certain aspects, have common traits and are involved in the results of the research. The researcher must identify the framework of the statistical population prior to commencement of research, in order to both determine his/her own assignment and introduce it easily to others. The statistical population is also called target population. The statistical population of the present research includes all managers of public and private banks (60 branches) in the North Khorasan Province. Since the research is not based on statistical analysis, there is no need to determine the statistical population and sample. Hence, a team of experts including higher educated employees and managers with a high tenure was employed. In this research, the decision-making team consists of 120 managers and employees of private and public banks of the North Khorasan Province.

Data collection is one of the most important stages of the research. The data needed to conduct the research can be collected in different ways. Various tools such as observation, interviews, questionnaires, documents, etc. are available for obtaining data. Each one has its own advantages and disadvantages that should be considered when using them so that the validity of the research is not compromised and the strengths of the tool are reinforced. Each researcher should choose one or more tools according to the nature of the problem and the hypotheses, and use them to collect data after obtaining their validity, and ultimately judge the hypotheses through data processing and analysis. The choice of tools should be such that the researcher can defend his choice and thereby validate his research achievements (Paradis et al., 2016).

\section{Fuzzy Analytic Hierarchy Process}

Analytic Hierarchy Process is a multi-criteria measurement that deals with both tangible and intangible criteria. All criteria were intangible before measurement scales were invented (Saaty, 2016). In addition, there are numerous situations and people on whose subjective preferences utility is dependent, regardless of what the measurement values express. Analytic Hierarchy Process was originally developed by Saaty (1980). This method is one of multi-attribute decision-making (MADM) techniques used to decide and select an option 

A. R. Afshari
Identifying and ranking the financial parameters of banks
et al. using fuzzy AHP method

among multiple options according to the indices determined by the decision maker. AHP provides a framework for team collaboration and participation in decision-making or problem solving. In addition, the requirement for pair-wise comparisons in AHP is one of the advantages of this method, since it forces a decision maker to reflect more on the factors weights and perform indepth analysis. Furthermore, another advantage of AHP is its ability to measure quantitative and qualitative criteria, so that mental preferences, expert knowledge and objective information are used in AHP. As regards the above-mentioned subject, it should be noted that although experts use their competencies and mental skills to make comparisons, the AHP does not have the potential to fully reflect the human thinking style. Therefore, fuzzy sets (Zadeh, 1965) are more compatible with linguistic (Herrera \& Herrera-Viedma, 2000) and sometimes vague human descriptions and they are best used for long-term predictions and real-world decisions. Since the numbers used in this study are triangular fuzzy numbers (TFNs), the fuzzy scales used in Analytic Hierarchy Process are shown in Table 1 and Figure 1.

Table 1: Linguistic scales expressing the degree of importance

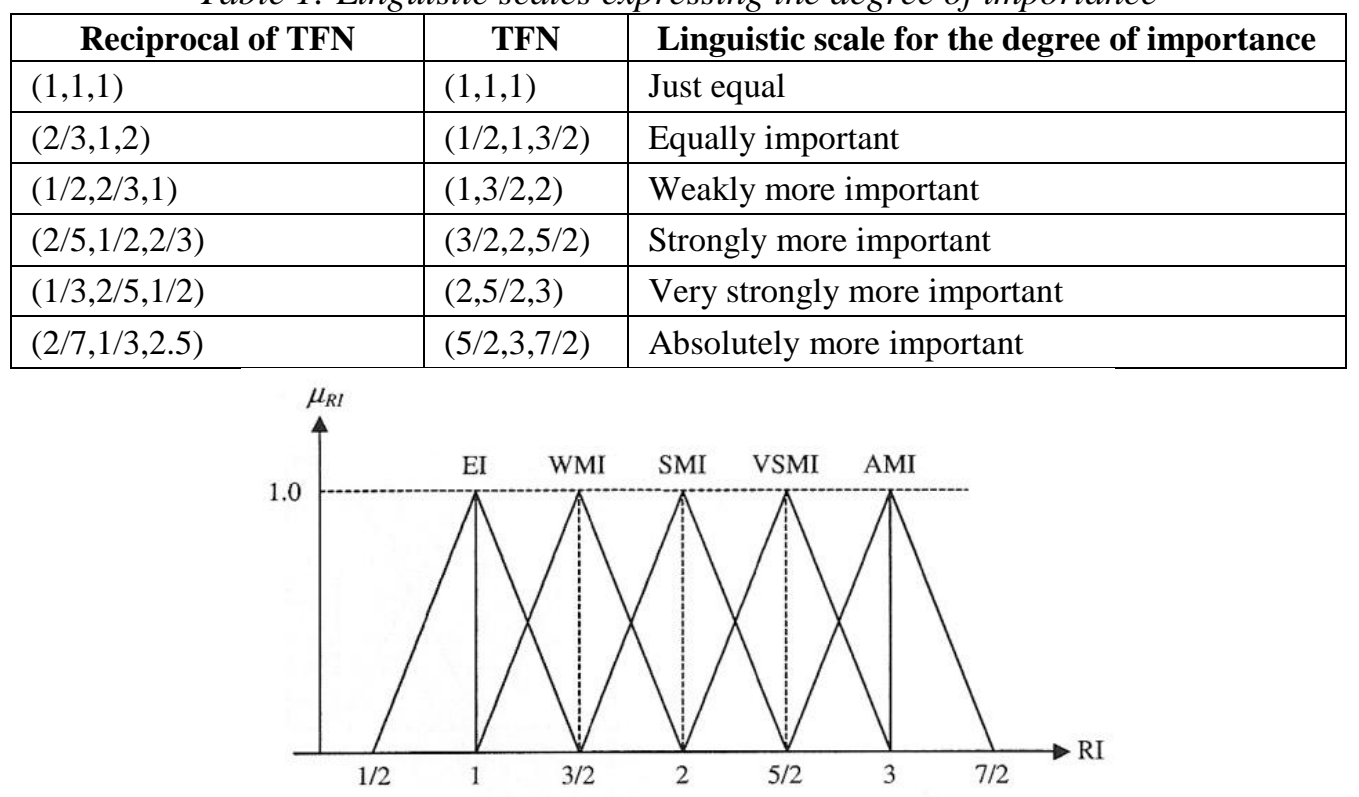

Figure 1: Linguistic scales expressing the degree of importance

In the following, the method of fuzzy Analytic Hierarchy Process is expressed in Chang's view (Van Laarhoven \& Pedrycz, 1983). In 1983, two Dutch scholars Laarhoren and Padrycz proposed a method for fuzzy Analytic Hierarchy Process based on the logarithmic least squares technique (Van Laarhoven \& Pedrycz, 1983). This method did not turn popular because of the complicated phases of implementation. In 1996, another method called Extent Analysis Method (EA) was suggested by a Chinese scholar, Chang (1996). The numbers used in this method are triangular fuzzy numbers. Concepts and definitions of fuzzy AHP based on extent analysis method would be described. Take the two triangular numbers of $M_{1}=\left(l_{1}, m_{1}, u_{1}\right)$ and $M_{2}=\left(l_{2}, m_{2}, u_{2}\right)$ that are indicated in Figure 2.

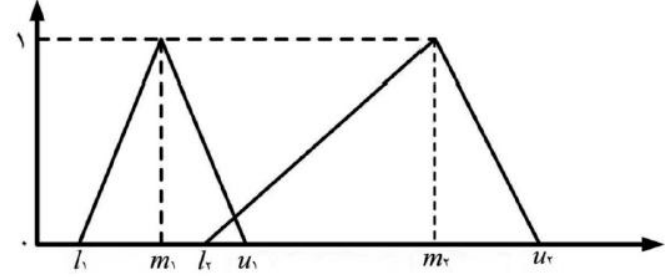

Figure 2: Linguistic scales expressing the degree of importance

Mathematical operators are defined for them as:

$$
\begin{aligned}
& M_{1}+M_{2}=\left(l_{1}+l_{2}, m_{1}+m_{2}, u_{1}+u_{2}\right) \\
& M_{1} \cdot M_{2}=\left(l_{1} \cdot l_{2}, m_{1} \cdot m_{2}, u_{1} \cdot u_{2}\right) \\
& M_{1}^{-1}=\left(\frac{1}{u_{1}}, \frac{1}{m_{1}}, \frac{1}{l_{1}}\right), M_{2}^{-1}=\left(\frac{1}{u_{2}}, \frac{1}{m_{2}}, \frac{1}{l_{2}}\right)
\end{aligned}
$$


It should be noted that the product of two triangular fuzzy numbers (Chou, 2003) or the reciprocal of a triangular fuzzy number are not a triangular fuzzy number anymore. These relations only express an approximation of real product of two triangular fuzzy numbers. In Extent Analysis Method, a value of $S_{k}$ that itself is a triangular number is calculated for each row of the pair-wise comparison matrix:

$$
S_{k}=\sum_{j=1}^{n} M_{k j} *\left[\sum_{i=1}^{m} \sum_{j=1}^{n} M_{i j}\right]^{-1}
$$

Where, $\mathrm{k}$ denotes the row number, while $\mathrm{i}$ and $\mathrm{j}$ are the choice number and index number, respectively. In Extent Analysis Method, the calculation of $S_{k}$ values is followed by calculating their degree of greatness relative to each other. Generally, if M1 and M2 are two triangular fuzzy numbers, the degree of greatness for M1 over M2 shown as V $\left(\mathrm{M}_{1}>\mathrm{M}_{2}\right)$ is defined as:

$$
\begin{cases}V\left(M_{1} \geq M_{2}\right) & f m_{1} \geq m_{2} \\ V\left(M_{1} \geq M_{2}\right)=\operatorname{hgt}\left(M_{1} \cap M_{2}\right) & \text { otherwise }\end{cases}
$$

Also,

$$
\operatorname{hgt}\left(M_{1} \cap M_{2}\right)=\frac{u_{1}-l_{2}}{\left(u_{1}-l_{2}\right)+\left(m_{2}-m_{1}\right)}
$$

The degree of greatness for a triangular fuzzy number over $\mathrm{k}$ other triangular fuzzy numbers would be given by the following equation:

$$
V\left(M_{1} \geq M_{2}, \ldots, M_{k}\right)=V\left(M_{1} \geq M_{2}\right), \ldots, V\left(M_{1} \geq M_{k}\right)
$$

The weight of indices in the pair-wise comparison matrix would be calculated as:

$$
W^{\prime}\left(x_{i}\right)=\operatorname{Min}\left\{V\left(S_{i} \geq S_{k}\right)\right\}, k=1,2, \ldots, n . k \neq i
$$

Therefore, the weight vectors for the indices would be:

$$
W^{\prime}\left(x_{i}\right)=\left[W^{\prime}\left(c_{1}\right), W^{\prime}\left(c_{2}\right), \ldots, W^{\prime}\left(c_{n}\right)\right]^{T}
$$

that are identical to non-normalized Fuzzy AHP coefficients vectors. By equation (9), nonnormalized results obtained from equation (8) are normalized. The normalized results of equation (9) are called $\mathrm{W}$.

$$
W_{i}=\frac{w_{1}^{\prime}}{\sum w_{i}^{\prime}}
$$

The statistical population of the present research includes all managers of public and private banks (60 branches) in the North Khorasan Province, Iran. Since the research is not based on statistical analysis, there is no need to determine the statistical population and sample. Hence, a panel of experts including higher educated employees and managers with a high tenure was employed. In this research, the decision-making team consists of 120 managers and employees of private and public banks of the North Khorasan Province. Accordingly, the steps of this study are based on Figure 3:

The variables of the present study were selected based on the main factors and sub-factors for the questionnaire presented in Table 2. 
A. $R$. Afshari Identifying and ranking the financial parameters of banks

et al. using fuzzy AHP method

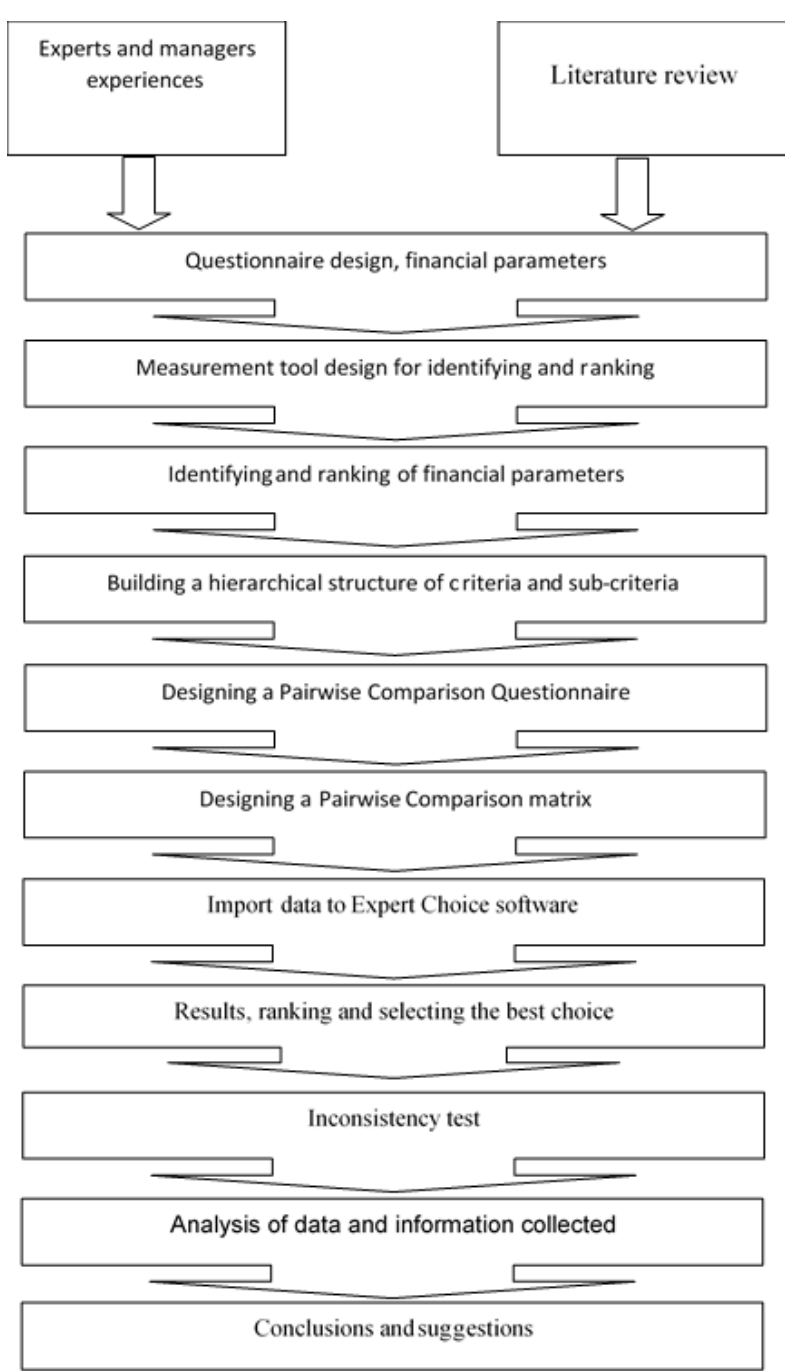

Figure 3: Steps in Research Process

Table 2: Introducing the Criteria \& Sub Criteria

\begin{tabular}{|c|c|c|c|c|}
\hline \multicolumn{3}{|c|}{ Criteria \& Sub Criteria } & \multicolumn{2}{|l|}{ Description and Code } \\
\hline \multirow{9}{*}{ A } & \multirow{3}{*}{ Profitability } & \multirow{3}{*}{ A1 } & Return on equity & A11 \\
\hline & & & Return on assets & $\mathrm{A} 12$ \\
\hline & & & Earnings per share & $\mathrm{A} 13$ \\
\hline & \multirow{3}{*}{ Liquidity } & \multirow{3}{*}{ A2 } & Instantaneous ratio & $\mathrm{A} 21$ \\
\hline & & & Current ratio & $\mathrm{A} 22$ \\
\hline & & & Cash flow from operating activities & $\mathrm{A} 23$ \\
\hline & \multirow{3}{*}{ Capital structure } & \multirow{3}{*}{ A3 } & Total debt-to-asset ratio & $\mathrm{A} 31$ \\
\hline & & & Short-term debt ratio & $\mathrm{A} 32$ \\
\hline & & & Long-term debt ratio & A33 \\
\hline \multirow{9}{*}{ B } & \multirow{3}{*}{ Environmental factors } & \multirow{3}{*}{ B1 } & The power of market competition & B12 \\
\hline & & & Government intervention rate & B13 \\
\hline & & & Governing rules and regulations & B13 \\
\hline & \multirow{3}{*}{ Credit history } & \multirow{3}{*}{ B2 } & Compliance with obligations & B21 \\
\hline & & & A reputation & B22 \\
\hline & & & customer satisfaction & B23 \\
\hline & \multirow{3}{*}{ Credit philosophy } & \multirow{3}{*}{ B3 } & Personnel quality & B31 \\
\hline & & & Team structure & B32 \\
\hline & & & Credit culture & B33 \\
\hline
\end{tabular}


A. R. Afshari Identifying and ranking the financial parameters of banks

et al. using fuzzy AHP method

\section{RESULTS}

To analyze the data obtained from data collection, AHP technique and Expert Choice software (Ishizaka \& Labib, 2009) are used. Using AHP method, the relative weight and the rank of each factor are determined. In this step, to calculate the relative importance (weight) of each main factor, a questionnaire was prepared and distributed in accordance with FAHP questionnaire (pair-wise comparison). The questionnaire consists of a matrix for pair-wise comparison of the factors. Given that level, one has two factors, the number of comparisons or questions is equal to:

$$
\frac{n(n-1)}{2}=\frac{2(2-1)}{2}=1
$$

After completing the questionnaires, the inconsistency rates of each expert were examined separately. Finally, 25 questionnaires were analyzed. Using EXCEL software (Palcic \& Lalic, 2009), individual opinions (geometric mean) were combined. After calculation of weights of profitability sub-factors $A_{1}, A_{2}, A_{3}$, ranking results for the profitability sub-factors are shown in Table 4.

After calculation of weights of profitability subfactors $\mathrm{B}_{1}, \mathrm{~B}_{2}, \mathrm{~B}_{3}$, ranking results for the profitability sub-factors are shown in Table 5 .

The random variable is extracted from the table below. In the final sub-weight, the factors of each group are equal to the product of the local weight of the elements by the weight of their head (the main factors) and finally the maximum rank of each of the identification and ranking of financial parameters of the public and private banks is determined; the results of this step are listed in Table 6.

Table 4: Pair-wise comparison matrix for variables sub-criteria of profitability

\begin{tabular}{|l|c|c|c|c|c|}
\hline A1 & A11 & A12 & A13 & Weight & Rank \\
\hline A11 & $(1,1,1)$ & $(0.93,1.17,1.44)$ & $(0.80,1.17,1.56)$ & $(0.379)$ & 1 \\
\hline A12 & $(0.69,0.85,1.07)$ & $(1,1,1)$ & $(1.02,1.33,1.89)$ & $(0.358)$ & 2 \\
\hline $\mathbf{A 1 3}$ & $(0.64,0.85,1.25)$ & $(0.52,0.75,0.98)$ & $(1,1,1)$ & $(0.262)$ & 3 \\
\hline & & & & & \\
\hline A2 & $\mathbf{A 2 1}$ & $\mathbf{A 2 2}$ & $\mathbf{A 2 3}$ & Weight & Rank \\
\hline $\mathbf{A 2 1}$ & $(1,1,1)$ & $(1.39,1.67,2.17)$ & $(0.54,0.74,0.97)$ & $(0.393)$ & 1 \\
\hline $\mathbf{A 2 2}$ & $(0.46,0.60,0.72)$ & $(1,1,1)$ & $(0.89,1.00,1.33)$ & $(0.225)$ & 3 \\
\hline $\mathbf{A 2 3}$ & $(1.03,1.35,1.85)$ & $(0.75,1.00,1.12)$ & $(1,1,1)$ & $(0.382)$ & 2 \\
\hline & & & & & \\
\hline $\mathbf{A 3}$ & $\mathbf{A 3 1}$ & $\mathbf{A 3 2}$ & $\mathbf{A 3 3}$ & Weight & Rank \\
\hline $\mathbf{A 3 1}$ & $(1,1,1)$ & $(0.97,1.26,1.61)$ & $(0.38,0.46,0.61)$ & $(0.157)$ & 2 \\
\hline $\mathbf{A 3 2}$ & $(0.62,0.79,1.04)$ & $(1,1,1)$ & $(1.00,1.00 .1 .00)$ & $(0.085)$ & 3 \\
\hline $\mathbf{A 3 3}$ & $(1.65,2.15,2.66)$ & $(1.00,1.00,1.00)$ & $(1,1,1)$ & $(0.759)$ & 1 \\
\hline
\end{tabular}

Table 5: Pair-wise comparison matrix for variables sub-criteria of environmental factors

\begin{tabular}{|l|c|c|c|c|c|}
\hline B1 & B11 & B12 & B13 & Weight & Rank \\
\hline B11 & $(1,1,1)$ & $(0.52,0.56,0.60)$ & $(0.71,0.91,1.13)$ & $(0.071)$ & $\mathbf{3}$ \\
\hline B12 & $(1.66,1.78,1.92)$ & $(1,1,1)$ & $(0.61,0.80,1.00)$ & $(0.496)$ & $\mathbf{1}$ \\
\hline B13 & $(0.88,1.09,1.40)$ & $(1.00,1.25,1.63)$ & $(1,1,1)$ & $(0.433)$ & $\mathbf{2}$ \\
\hline & & & & & \\
\hline B2 & B21 & B22 & B23 & Weight & Rank \\
\hline B21 & $(1,1,1)$ & $(1.50,1.83,2.17)$ & $(0.50,0.89,1.33)$ & $(0.371)$ & $\mathbf{2}$ \\
\hline B22 & $(0.46,0.55,0.66)$ & $(1,1,1)$ & $(2.17,2.67,3.17)$ & $(0.446)$ & $\mathbf{1}$ \\
\hline B23 & $(0.75,1.12,2.00)$ & $(0.31,0.37,0.46)$ & $(1,1,1)$ & $(0.183)$ & $\mathbf{3}$ \\
\hline & & & & & \\
\hline B3 & B31 & $\mathbf{B 3 2}$ & $\mathbf{B 3 3}$ & Weight & Rank \\
\hline B31 & $(1,1,1)$ & $(0.94,1.33,2.17)$ & $(1.30,1.50,1.72)$ & $(0.494)$ & $\mathbf{1}$ \\
\hline B32 & $(0.46,0.75,1.06)$ & $(1,1,1)$ & $(1.19,1.50,2.06)$ & $(0.392)$ & $\mathbf{2}$ \\
\hline B33 & $(0.58,0.66,0.77)$ & $(0.48,0.66,0.84)$ & $(1,1,1)$ & $(0.115)$ & $\mathbf{3}$ \\
\hline
\end{tabular}


A. $R$. Afshari Identifying and ranking the financial parameters of banks

et al. using fuzzy AHP method

Table 6: Identifying and ranking the financial parameters based on FAHP method

\begin{tabular}{|c|c|c|c|c|c|}
\hline Sub-factors & Weight & Indices & Weight & Final weight & Rank (priority) \\
\hline \multirow{3}{*}{ A1 } & \multirow{3}{*}{0.311} & A11 & 0.379 & 0.065 & 6 \\
\hline & & A12 & 0.358 & 0.062 & 9 \\
\hline & & A13 & 0.262 & 0.045 & 13 \\
\hline \multirow{3}{*}{ A2 } & \multirow{3}{*}{0.488} & A21 & 0.393 & 0.106 & 1 \\
\hline & & A22 & 0.225 & 0.061 & 10 \\
\hline & & A23 & 0.382 & 0.103 & 2 \\
\hline \multirow{3}{*}{ A3 } & \multirow{3}{*}{0.201} & A31 & 0.157 & 0.017 & 16 \\
\hline & & A32 & 0.085 & 0.009 & 18 \\
\hline & & A33 & 0.759 & 0.084 & 3 \\
\hline \multirow{3}{*}{ B1 } & \multirow{3}{*}{0.324} & B11 & 0.071 & 0.010 & 17 \\
\hline & & B12 & 0.496 & 0.071 & 5 \\
\hline & & B13 & 0.433 & 0.063 & 8 \\
\hline \multirow{3}{*}{ B2 } & \multirow{3}{*}{0.306} & B21 & 0.371 & 0.051 & 12 \\
\hline & & B22 & 0.446 & 0.059 & 11 \\
\hline & & B23 & 0.183 & 0.025 & 14 \\
\hline \multirow{3}{*}{ B3 } & \multirow{3}{*}{0.369} & B31 & 0.494 & 0.081 & 4 \\
\hline & & B32 & 0.392 & 0.064 & 7 \\
\hline & & B33 & 0.115 & 0.019 & 15 \\
\hline
\end{tabular}

Table 7: Ranking the variables factors

\begin{tabular}{|l|c|c|}
\hline \multicolumn{1}{|c|}{ Factors } & Relative weights & Rank \\
\hline Profitability & 0.311 & 4 \\
\hline Liquidity & 0.488 & 1 \\
\hline Capital structure & 0.201 & 6 \\
\hline Environmental factors & 0.324 & 3 \\
\hline Credit history & 0.306 & 4 \\
\hline Credit philosophy & 0.369 & 2 \\
\hline
\end{tabular}

Table 7 lists the ranking of factors influencing financial parameters of the banks. As shown in Table 7, the liquidity variable has the first rank followed by credit philosophy.

\section{CONCLUSION}

Degrees of credit, profitability and liquidity are among the most important criteria for determining the competency and measuring a bank's activities. According to the results of the present study, the perceived quality of financial services is one of the most important factors affecting bank customer loyalty, so measuring continuously the level of perceived quality of financial services should be considered by banks and their managers. Today, the perceived quality of financial services is one of the most important factors for the success of organizations in business and profitability. Therefore, the establishment and implementation of measurement and monitoring systems for the perceived quality of financial services is considered as one of the most important indicators and needs of today's organizations.
Employment of a relevant marketing strategy will lead to strong links with customers and will have many competitive advantages, including attracting customers from other banks. As a result, managers and decision makers of banks are recommended to provide strong and sustainable relations with valued customers and leverage its competitive advantages. Building lasting relationship with customers provides benefits for the organization through customer satisfaction, customer loyalty and customer perception of financial service quality. To this end, it is essential to take the required measures to win the trust of bank customers, to make them be committed, to create appropriate communication channels with customers in order to be aware of their interests and needs, and to control and manage their interest conflicts. Based on the results of this study, customer loyalty is considered as one of the factors affecting the financial performance of private banks. Organizations that account for a larger share of loyal customers will significantly increase their profitability. In this regard, bank managers and decision makers are encouraged to develop plans to build loyalty in their customers. Nowadays, 
marketing strategies focus on the improvement of customer retention and customer loyalty. The main reason for this emphasis is the awareness of the economic consequences of customer loyalty. A bank must strive to be far from break-even point and be closer to the safety margin as its operations expand. Since bad debts in banks with a high profitability ratio is less than banks with low profitability ratios, so financial institutions and banks, central bank and other creditors will have less debt collection risk. Therefore, they can make decision to provide credit to the respective banks. Profitability affects the deposit-to-assets ratio. Since banks are responsible for equipping and distributing credits, credit operations, financial operations, foreign currency sale and purchase, and other banking services, banks with high profitability are therefore recommended to finance through deposits, and investors will pay attention to the profitability of banks when depositing money in banks.

\section{REFERENCES}

Abubakar, A. M., Elrehail, H., Alatailat, M. A., \& Elçi, A. (2019). Knowledge management, decisionmaking style and organizational performance. Journal of Innovation Knowledge, 4(2), 104-114. https://doi.org/10.1016/j.jik.2017.07.003

Amile, M., Sedaghat, M., \& Poorhossein, M. (2013). Performance Evaluation of Banks using Fuzzy AHP and TOPSIS, Case study: State-owned Banks, Partially Private and Private Banks in Iran. Caspian Journal of Applied Sciences Research, 2(3).

Barth, M. E., Cram, D. P., \& Nelson, K. K. (2001). Accruals and the prediction of future cash flows. The Accounting Review, 76(1), 27-58. https://doi.org/10.2308/accr.2001.76.1.27

Beck, T. (2008). Bank competition and financial stability: friends or foes? : The World Bank.

Berger, A. N., \& Bouwman, C. H. (2013). How does capital affect bank performance during financial crises? Journal of Financial Economics, 109(1), 146-176. https://doi.org/10.1016/j.jfineco.2013.02.008

Bouma, J. J., Jeucken, M., \& Klinkers, L. (2017). Sustainable banking: The greening of finance. Routledge.

Bowen, R. M., Burgstahler, D., \& Daley, L. A. (1987). The incremental information content of accrual versus cash flows. Accounting Review, 62(4), 723747.

Bowen, R. M., Burgstahler, D., \& Daley, L. A. J. A. R. (1986). Evidence on the relationships between earnings and various measures of cash flow. Accounting Review, 61(4), 713-725.

Chang, D.-Y. (1996). Applications of the extent analysis method on fuzzy AHP. European Journal of
Operational Research, 95(3), 649-655. https://doi.org/10.1016/0377-2217(95)00300-2

Chou, C.-C. (2003). The canonical representation of multiplication operation on triangular fuzzy numbers. Computers Mathematics with Applications, 45(10-11), 1601-1610. https://doi.org/10.1016/S0898-1221(03)00139-1

Cilizoglu, M. (2018). Ending Economic Coercion and the Consequences of Sanctions Removal. The University of North Carolina at Chapel Hill,

Cohen, D. A., Lys, T. (2006). Weighing the evidence on the relation between external corporate financing activities, accruals and stock returns. Journal of Accounting and Economics, 42(1-2), 87-105. https://doi.org/10.1016/j.jacceco.2006.04.006

De Haan, J., Oosterloo, S., \& Schoenmaker, D. (2009). European financial markets and institutions. Cambridge University Press.

Fund, I. M., \& Bank, W. (2017). People's Republic of China Financial Sector Assessment Program: IOSCO Objectives and Principals of Securities Regulation. World Bank.

Gordon, E. A., Henry, E., Jorgensen, B. N., \& Linthicum, C. L. (2017). Flexibility in cash-flow classification under IFRS: determinants and consequences. Review of Accounting Studies, 22(2), 839-872.

Hermes, N., \& Hudon, M. (2018). Determinants of the performance of microfinance institutions: A systematic review. Journal of Economic Surveys, 32(5), 1483-1513.

https://doi.org/10.1111/joes.12290

Herrera, F., \& Herrera-Viedma, E. (2000). Linguistic decision analysis: steps for solving decision problems under linguistic information. Fuzzy Sets and Systems, 115(1), 67-82. https://doi.org/10.1016/S0165-0114(99)00024-X

Ishizaka, A., \& Labib, A. (2009). Analytic hierarchy process and expert choice: Benefits and limitations. Or Insight, 22(4), 201-220. https://doi.org/10.1057/ori.2009.10

Kashyap, A. K., Rajan, R., \& Stein, J. C. (2002). Banks as liquidity providers: An explanation for the coexistence of lending and deposit-taking. The Journal of Finance, 57(1), 33-73. https://doi.org/10.1111/1540-6261.00415

Kothari, J., \& Barone, E. (2006). Financial accounting. an international approach. Pearson Education.

Morozko, N., Morozko, N., \& Didenko, V. (2018). Modeling the process of financing small organizations. Journal of Reviews on Global Economics, 7, 774-783.

Nikpour, S., Bahmani, M., Jalaee, S. A., \& Nejati, M. (2018). Financial Integration between Iran, OPEC and the Shanghai Organization. Iranian Journal of Finance, 2(4), 78-105.

Palcic, I., \& Lalic, B. (2009). Analytical Hierarchy Process as a tool for selecting and evaluating projects. International Journal of Simulation Modelling, 8(1). 
Paradis, E., O'Brien, B., Nimmon, L., Bandiera, G., \& Martimianakis, M. A. T. (2016). Design: Selection of data collection methods. Journal of Graduate Medical Education, 8(2), 263. https://doi.org/10.4300/JGME-D-16-00098.1

Pilbeam, K. (2018). Finance \& financial markets. Macmillan International Higher Education.

Puro, M. (1984). Audit firm lobbying before the Financial Accounting Standards Board: An empirical study. Journal of Accounting Research, 624-646. https://doi.org/10.2307/2490668

Saaty, T. L. (1980). The Analytic Hierarchy Process. New York. McGraw-Hill.

Saaty, T. L. (2016). The analytic hierarchy and analytic network processes for the measurement of intangible criteria and for decision-making. In Multiple criteria decision analysis (pp. 363-419): Springer.

Sirmon, D. G., Hitt, M. A., Ireland, R. D., \& Gilbert, B. A. (2011). Resource orchestration to create competitive advantage: Breadth, depth, and life cycle effects. Journal of Management, 37(5), 1390-

1412. https://doi.org/10.1177/0149206310385695

Van Laarhoven, P. J., \& Pedrycz, W. (1983). A fuzzy extension of Saaty's priority theory. Fuzzy Sets Systems, 11(1-3), 229-241. https://doi.org/10.1016/S0165-0114(83)80082-7

Wyplosz, C. (2002). How risky is financial liberalization in the developing countries? Comparative Economic Studies, 44(2), 1-26. https://doi.org/10.1057/ces.2002.7

Yoshino, N., \& Taghizadeh-Hesary, F. (2017). Alternatives to bank finance: Role of carbon tax and hometown investment trust funds in developing green energy projects in Asia. http://hdl.handle.net/10419/179217

Zadeh, L. A. (1965). Fuzzy sets. Information and Control, 8(3), 338-353. https://doi.org/10.1142/9789814261302_0021

\title{
IDENTIFIKACIJA I RANGIRANJE FINANSIJSKIH PARAMETARA BANAKA KORIŠĆENJEM FUZZY AHP METODE
}

\begin{abstract}
Ova studija je sprovedena sa ciljem da identifikuje i rangira finansijske parametre javnih i privatnih banaka u provinciji Severni Horasan. Metodologija studije zasnivala se na kvantitativnom i presečnom istraživanju sa uporednim i terenskim studijama. U ovom istraživanju, nakon proučavanja bibliotečkih istraživanja i studija i usmenih intervjua, postavljeni su upitnici finansijskih parametara banaka. Pored toga, istraživanje je obuhvatilo 120 zaposlenih i 60 menadžera filijala državnih i privatnih banaka u provinciji Severni Horasan. Dobijeni podaci analizirani su AHP metodom za rangiranje faktora pomoću softvera Expert Choice. Rezultati su pokazali da je trenutni faktor sa relativnom težinom od 0,106 u prvom rangu, a nakon toga je operativni novčani tok koji se može pripisati operativnim aktivnostima sa relativnom težinom od 0,103 rangiran kao drugi, dok je odnos dugoročnog duga sa relativnom težinom od 0,084 rangiran kao treći po značaju finansijskih parametara banaka.
\end{abstract}

Ključne reči: Učinak banke; Procena učinka; Fuzzy analitički hijerarhijski proces (FAHP); Višekriterijumsko odlučivanje (MCDM); Fuzzy donošenje odluka. 